\title{
Environmental education in the language and literature learning in elementary education
}

Lustyantie, Ninuk $₫$

State University of Jakarta, Indonesia(lustyantie@yahoo.com)

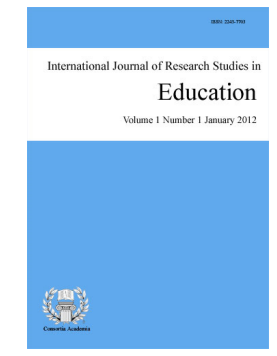

Accepted: 3 January 2015 Online ISSN: $2243-7711$

OPEN ACCESS

\section{Abstract}

Environmental education is a process to build the world's human population awareness and concerned about the total environment and all the problems associated with it, and people who have the knowledge, skills, attitudes and behavior, motivation and commitment to work together, either individually and collectively, in order to solve a wide range of current environmental issues, and prevent new problems. Basically, this life balanced the harmony among all things in this world. The living things such as humans, animals and plants, and all the inanimate objects have their own role in this life. It is the human being that makes the environment destructed and no longer well arranged. In implementing the living environmental education, the main actor is human being, and the main focus is on the management of the environment through environmental education from primary education to higher education and to the community. The content of living environment is delivered integratedly at the primary education in the curriculum system by incorporating the themes about living environment. Learning a language is essentially learning to communicate in various contexts of communication. Therefore, the language learning in the curriculum in Indonesia is directed to improve the learner's ability to communicate, which may include environmental education both in oral and written modes. Learning the literature is learning the meanings through the values, one of which is through the way the values of environmental education are applied in learning the language and literature in elementary education.

Keywords: environmental education; language learning; literature learning; elementary education; sustainability 


\section{Environmental education in the language and literature learning in elementary education}

\section{Introduction}

Education is influenced by both internal and external environments. One of the external education environments is the education in family environment. From this smallest environment, i.e. family, environmental education can begin. Family plays an important role in the environmental education because family is an education spearhead for the children. The most concrete form of education in the family is educating the children to throw away garbage into the bins that have been provided. If children have been educated with a good understanding of the environment since their early childhood, the environmental education at school will run well and will get a good response from the students and eventually the environmental destructions and problems caused by the daily life activities can be reduced or even avoided.

Learning a language is essentially learning to communicate. Therefore, language learning is directed to improve the learners' ability to communicate, in both oral and written modes. Language ability means language learners are skilled in using language as a communication tool. A skilled language user means having good skill in listening, speaking, reading, and writing in the language. Language learners do not only comprehend the language but at the same time they are also expected to have knowledge so as to have a positive attitude towards literature.

In 2013, Indonesia experienced a curriculum development in which it is mentioned that the purpose of language learning is language learners are directed into four sub-aspects of language skills, namely reading, speaking, writing, and listening. The skills developed are the ability to catch the meaning, to play the role, to interpret, to assess, and to express themselves by using language. For this purpose, in elementary education, environmental education begins to be given through language and literature. All of them are grouped into language, comprehension, and utilization toward the environmental education (Source: Ministry of Education and Culture of the Republic of Indonesia).

\subsection{Focus of the Research}

Based on the background of the problem that has been mentioned, the focus of this research is how is the lesson material of environmental education in language and literature learning in elementary education in Indonesia.

\section{Theoretical Review}

\subsection{Curriculum}

In accordance with the time development and challenges, the curriculum in Indonesia needs to be developed. The Curriculum Development in 2013 is based on the juridical provision issuing the obligation to develop new curriculum, philosophical base, and empirical base. Juridical base is a legal provision that makes the basis for curriculum development and requires the development of a new curriculum. Philosophical base is the one directing the curriculum to which human being will be produced by the curriculum. Theoretical base provides theoretical bases of curriculum development as documents and processes. Empirical base gives directions based on the implementation of the curriculum that is being applied in the field.

This curriculum is also based on the competency-based curriculum model characterized by the competency development including attitudes, knowledge, thinking skills, and psychomotoric skills which are packaged in a 
Environmental education in the language and literature learning in elementary education

variety of subjects. The elements developed in the 2013 curriculum (Source: Ministry of Education and Culture of the Republic of Indonesia), are:

Graduates Competency Standard - Within this case the learners are expected to show the improvement and the balance between soft skills and hard skills which include attitude competence aspects (including: personal faith, morality, self-confidence, and responsibility in interacting effectively with social environment, natural environment, as well as with the world and its civilization), skills (including: personal capability of thinking and doing which is effective and creative in the abstract and concrete domain), and knowledge (including: the ability to produce personality mastering science, technology, arts, culture in the concept of humanitarian, nationality, statesmanship, and civilization).

Content Standard - A competency which used to derive from the subjects turns into subjects developed from the competency. Competencies developed are through

$>\quad$ Integrative thematic in all subjects in all grades at Elementary School

$>\quad$ The subjects in all grades at Junior High School and Senior High School

$>\quad$ Vocational in all grades at Vocational School

Referring to the concept of the 2013 Curriculum, it can be concluded that the graduates competency standard of education in Indonesia is expected to show the improvement and the balance between soft skills and hard skills that include attitude competence aspects (including: personal faith, morality, self-confidence, and responsibility in interacting effectively with social environment, natural environment, as well as with the world and its civilization). The content standard for elementary education level is delivered through Integrative Thematic in all subjects.

\subsection{Elementary Education in Indonesia}

The education system in Indonesia consists of Elementary Education, Secondary Education, and Higher Education. Elementary education is an education level that underlies secondary education level. Every citizen aged seven to fifteen years must take this elementary education. The Indonesian Government and the Local Government guarantee that the implementation of compulsory education for every citizen over the age of 6 (six) years in the level of elementary education is free of charge. Elementary education is in the form of elementary school (SD) and Islamic Elementary School (MI) or other equivalent forms; as well as Junior High School (SMP) and Islamic Junior High School (MTs), or other equivalent forms.

Meanwhile, secondary education is a continuation of elementary education. Secondary education consists of general secondary education and vocational education. Secondary education is in the form of Senior High School (SMA), Islamic Senior High School (MA), Vocational School (SMK), and Islamic Vocational School (MAK), or other equivalent forms. Meanwhile, higher education means an education level taken after secondary education that includes diploma, bachelor, master, specialist, and doctoral degrees managed by college. The college may take the form of academic colleges, polytechnics, high schools, institutes, or universities.

Based on the description of the education system in Indonesia, it can be concluded that the definition of elementary education in Indonesia is an education level underlying secondary education and compulsory for every Islamic Elementary School (MI) (Source: Ministry of Education and Culture of the Republic of Indonesia).

\subsection{Environmental Education}

Living environment is a unit of space with all things, forces, conditions, and living things, including human beings and their behavior, which affects the survival and the prosperity of humans and other living creatures. The condition of very rapid population growth leads to the increase of all the needs both individual and social needs. 
Each individual has always wanted to meet their needs, and at the same time the government is required to meet the demands needed by all citizens. The fulfillment of these needs may lead to environmental problems. Environmental problems are the conditions in the environment that impede the fulfillment of human's needs for health and happiness (James \& Stapp, 1974, p. 20). Environmental problems faced today are caused by the actions of humans themselves who are never satisfied with their needs. Meeting this endless satisfaction causes environmental destructions. In other words, environmental problems arise because of the desire to meet the needs of both individual and social.

From some explanation above, it can be concluded that environmental education is an attempt to change the behavior and the attitude performed by various parties or elements of society that aims at improving the knowledge, skills and awareness of the society concerning the environmental values and environmental problems issues, which in turn can drive the community to play an active role in the preservation and safety of the environment for the benefit of present and future generations. In Indonesia, environmental education is the educational activity in the field of living environment implemented through schools, consisting of elementary education, secondary education, and higher education and is done in a structured and tiered way with an approach method of either integrated curriculum or monolithic curriculum.

\subsection{Language and Literature Learning}

Language is a system of arbitrary conventionalized symbols that enable members of a given society to communicate with one another (Brown, 2000, p. 5). Hadley adds that language is a structural system about arbitrary language sounds and sound sequences which is used, or which can be used in communication between individuals by a group of people and which is, in shorter words, used to name objects, events, and processes in the human living environment. In addition, Atherton asserts that language is an effective means of communication despite its imperfection; hence the imperfection of language as a means of communication becomes one of the sources to cause misunderstanding.

From some definition and explanation of language mentioned above, it can be concluded that language is a communication tool. As a tool of communication, language has certain functions and modes. Meanwhile, literature can be defined as an imaginative work that uses language as the medium and has dominant aesthetic function (Welle \& Warren, 1993, p. 14). In addition, Literature is a human personal expression including experiences, thoughts, feelings, ideas, spirits, and convictions in a concrete description that evokes enchantment by using language as a tool (Teew, 1983, p. 3).

Based on the previous opinions, it can be concluded that the language has an important role in literature and it can also be said that language cannot be separated from literature. As one of the branches of arts that requires a medium, as dance arts with motion medium, music arts with voice medium, then language acts as a medium of literature (Second order of Semiotics). This fact carries consequences that to understand a literary work needs the ability to understand its language. Furthermore, learning is a system that aims at assisting student's learning process, containing a series of events designed and arranged in such a way to influence and support the students' learning processes internally (Gagne \& Briggs, 1979, p. 3). Besides, in the Education Act No. 20/2003 it is stated that learning is a process of interaction of the learners with the teacher and the learning sources in a certain learning environment.

Learning is the assistance given by teachers or educators in order to run the process of science and knowledge acquisition, skills mastery and attitudes control, and character and confidence building to the learners. In other words, learning is a process to assist the learners to be able to learn well. Human experiences learning process during his life and can take place anywhere and anytime. In the context of education, teachers teach in order that students can learn and master the course contents until they achieve a certain specified objective (cognitive aspect), can also affect a change in attitude (affective aspect), and skills (psychomotor aspects) of the learners. This is confirmed by Sumardi saying that the term "learning" is similar with "instruction or teaching". 
Environmental education in the language and literature learning in elementary education

Teaching means ways of teaching or process of teaching (Sumardi, 1998, p. 22), so it can be said that learning is a process of interaction of the learners with the teacher and learning sources in a certain learning environment.

From some definition mentioned above it can be concluded that language and literature learning is the interaction of learners with teachers. Both language and literature play an important role in environmental education.

\section{Methodology}

The main purpose of this research is to obtain a deeper understanding of how is the environmental education contained in the language and literature learning in elementary education in Indonesia. The sub-focus of this research is how is environmental education in language and literature learning of fourth grade students at elementary school. Thus in detail, this study aims at:

$>\quad$ Obtaining a deep understanding about environmental education in language learning based on the book “Materi Pembelajaran Tematik Integratif Siswa Sekolah Dasar Kelas IV” (Learning Material of Integrative Thematic to the Fourth Grade Students of Elementary School).

$>\quad$ Obtaining a deep understanding about environmental education in literature learning based on the book "Materi Pembelajaran Tematik Integratif Siswa Sekolah Dasar Kelas IV" (Learning Material of Integrative Thematic to the Fourth Grade Students of Elementary School).

This research is done by using qualitative research design with content analysis method. As a qualitative research, the source of data is taken from the book "Materi Pembelajaran Tematik Integratif Siswa Sekolah Dasar Kelas IV" (Learning Material of Integrative Thematic to the Fourth Grade Students of Elementary School) in the form of words, phrases, sentences, and verbal texts. Meanwhile, a content analysis method is used to systematically analyze the data or the content/message of the text. A content analysis includes matters related to the aspects of language such as syntactic, referential, and propositional aspects. A syntactic aspect can be a sentence or a group of words in the text associated with the references or matters about living environment and the cohesion between sentences in the text. According to Miles and Huberman (1994), techniques of data analysis can be done by using words. Therefore, the data in this study are analyzed in the form words and sentences together with the interpretation of the lingual words.

\section{Research Findings}

In accordance with the 2013 curriculum applied in Indonesia since the academic year of 2013/2014, the learning material in the fourth grade of Elementary School is delivered through integrative thematic consisting of 9 themes. First, the theme is the Beauty of Togetherness; second, Always Conserving on Energy; third, Caring for Living Creatures; fourth, Various Jobs; fifth, Appreciating Heroes' Service; sixth, the Beauty of my Country; seventh, Ideals; eighth, the Area of My Residence; and the ninth, the theme is Healthy and Nutritious Food.

The theme analyzed in this research is the second theme, a theme related to the living environment that is "Always Conserving the Energy" with the sub-theme, Conserving the Energy at Home. The texts analyzed are the ones related to the theme "Always Conserving the Energy" from the book "Materi Pembelajaran Tematik Integratif Siswa Sekolah Dasar Kelas IV" (Learning Material of Integrative Thematic to the Fourth Grade Students of Elementary School) compiled by Nur Komariah et al. and published by CV Arya Duta in 2013. Besides referring to the second theme, the analysis also refers to the syllabus of the 2013 Curriculum about thematic learning of Indonesia language Subject in the fourth grade of Elementary School (see table 1). 


\section{Table 1}

The Syllabus of Thematic Learning of Bahasa Indonesia Subject

\begin{tabular}{|c|c|c|c|c|c|c|}
\hline $\begin{array}{c}\text { Main } \\
\text { Competence }\end{array}$ & $\begin{array}{c}\text { Basic } \\
\text { Competence }\end{array}$ & Indicator & Learning Activities & Assessment & $\begin{array}{c}\text { Time } \\
\text { Allocation }\end{array}$ & $\begin{array}{c}\text { Learning Tools } \\
\text { and Sources }\end{array}$ \\
\hline $\begin{array}{l}\text { Showing the } \\
\text { behaviour of } \\
\text { honesty, } \\
\text { discipline, } \\
\text { responsibility, } \\
\text { politeness, care, } \\
\text { and } \\
\text { self-confidence } \\
\text { in the interaction } \\
\text { with family, } \\
\text { friends, } \\
\text { teachers, and } \\
\text { neighbours } \\
\text { Presenting } \\
\text { factual } \\
\text { knowledge in } \\
\text { factual and } \\
\text { logical } \\
\text { language, in } \\
\text { aesthetic works, } \\
\text { in the actions } \\
\text { reflecting a } \\
\text { healthy student, } \\
\text { and in the } \\
\text { actions } \\
\text { reflecting a } \\
\text { faithful and } \\
\text { moral student }\end{array}$ & $\begin{array}{l}\text { Having a care } \\
\text { about forces, } \\
\text { movements, } \\
\text { heat energy, } \\
\text { sound energy, } \\
\text { light energy, } \\
\text { and alternative } \\
\text { energy through } \\
\text { the utilization } \\
\text { of Bahasa } \\
\text { Indonesia } \\
\text { Observing, } \\
\text { processing, } \\
\text { and presenting } \\
\text { the text } \\
\text { reporting the } \\
\text { observastion } \\
\text { result about } \\
\text { forces, } \\
\text { movements, } \\
\text { heat energy, } \\
\text { sound energy, } \\
\text { and light } \\
\text { energy in oral } \\
\text { and written } \\
\text { bahasa } \\
\text { Indonesia in } \\
\text { writing and } \\
\text { sorting } \\
\text { standard } \\
\text { vocabulary }\end{array}$ & $\begin{array}{l}\text { Showing the habit of } \\
\text { appreciating the } \\
\text { eistence of energy and } \\
\text { its changes } \\
\text { Making the text of } \\
\text { interview guidelines } \\
\text { about heat energy } \\
\text { sources (the content of } \\
\text { the interview } \\
\text { guidelines consists of } \\
\text { its source and its } \\
\text { advantages } \\
\text { Making the text of } \\
\text { interview guidelines } \\
\text { about alternative } \\
\text { energy sources (the } \\
\text { content of the } \\
\text { interview guidelines } \\
\text { consists of its source } \\
\text { and its advantages) } \\
\text { Doing the interview } \\
\text { with the informants } \\
\text { about the heat energy } \\
\text { sources and alternative } \\
\text { energy sources with a } \\
\text { proper phase } \\
\text { Making a report of the } \\
\text { result of the interview } \\
\text { about the heat energy } \\
\text { sources with a proper } \\
\text { phase } \\
\text { Making a report of the } \\
\text { result of the interview } \\
\text { ponergy sources with a } \\
\text { proper phase }\end{array}$ & $\begin{array}{l}\text { Learning } 1 \\
\text { Doing the observation } \\
\text { about energy and } \\
\text { living environment } \\
\text { Arranging the } \\
\text { questions } \\
\text { Learning } 2 \\
\text { Making the text of } \\
\text { interview guidelines } \\
\text { about energy source } \\
\text { Using oral speech } \\
\text { appropriate with } \\
\text { natural environment } \\
\text { Learning } 3 \\
\text { Discussing alternative } \\
\text { energy sources } \\
\text { Learning } 4 \\
\text { Doing the interview } \\
\text { with the informants } \\
\text { Showing a good } \\
\text { attitude in the } \\
\text { interaction with nature } \\
\text { Learning } 5 \\
\text { Making a report of the } \\
\text { result of the interview } \\
\text { about the heat energy } \\
\text { sources } \\
\text { Learning } 6 \\
\text { Discussing and } \\
\text { retelling the content of } \\
\text { the interview about } \\
\text { utilization of the } \\
\text { energy and living } \\
\text { environment }\end{array}$ & $\begin{array}{l}\text { Scoring } \\
\text { Rubric }\end{array}$ & $\begin{array}{c}7 \times 35 \\
\text { minutes }\end{array}$ & $\begin{array}{c}\text { Relevant } \\
\text { Reference } \\
\text { Books } \\
\text { Writing tools }\end{array}$ \\
\hline
\end{tabular}

Note. Theme: always conserving the energy. Sub-theme: 1. conserving the energy at home; 2 . conserving the energy at school; 3 . conserving the energy in the society environment.

The first sub-theme, "Conserving the Energy at Home" is found in learning activity 1, and the text is entitled "Using Energy at Mr. Rudi's House" (Penggunaan Energi di Rumah Pak Dudi). Based on the text, in accordance with learning activity 1 , i.e. doing observation about equipments at home, it is found that the text provides the exercise about observation which, in turn, answers the questions related to conserving the energy by using a good and correct Indonesia language (p. 8).

\section{Using Energy at Mr. Rudi's House (Penggunaan Energi di Rumah Pak Dudi)}

Saturday afternoon at Bima's house, all family members doing activities respectively. Dad is feeding his pet chickens and Mom is lifting the clothes. Milky and Dita are playing in the family room. Dita plays dolls and Milky plays toy cars.

"Bima, why don't my dolls move?" asked Dita to the Milky

"Perhaps the batteries are exhausted". Bima answeres and replaces the battery with a new one.

Once the battery is installed, the Bima shifts button from off to on. In that instant, Dita's dolls move as before.

"Wow, great. The dolls are able to move because the energy is up", Bima explains. "Therefore, if Dita finished playing those dolls, do not forget to turn it off. The on should be shifted to the off position", said Bima.

"Why should it be so, brother?" Asked Dita.

"It was to save battery energy quickly so as not to run out," said Bima.

"Oh, so yes. Well, I will remember the message brother,"said Dita, smiling.

After playing, Bima and Dita are picking up their toys. The toys are keep back in their place. They also wash their hands and feet in the bathroom. Before they get out of the bathroom, they don't forget to turn off the lights and water tap. Bima and Dita got used to implement the rules in his house. Father and mother always reminded to save energy. 


\section{Let's observe}

Do the observation on the equipments found in your home. Then answer the following questions by using a good and correct Bahasa Indonesia!

1. What kinds of energy are used in your home? (Energi apa saja yang digunakan di rumahmu?

2. What kind of energy is mostly used in your home? (Energi apakah yang paling banyak digunakan di rumahmu?)

3. What do your family do to conserve the energy? (Bagaimana cara keluargamu menghemat energi tersebut?

In learning activity 2, writing exercise is found. This exercise is in the form of making a list of questions by using vocabulary related to living environment.

Let's write a list of questions

Write several questions to look for the information related to heat energy including its sources and its advantages! (p. 12).

Meanwhile, the finding in learning activity 4 is doing the interview with the informants about living environment particularly about heat energy sources and alternative energy sources by using a proper phase. What follows is the interview phases found in learning activity 4 (p. 25).

I know - The phases of doing the interview:

$>\quad$ Prepare the list of questions that will be delivered

$>\quad$ Say a greeting when entering and leaving the house

$>$ Make sure that our targeted informants are ready to be interviewed

$>$ Behave and ask the informants politely

$>$ Don't force the informants to answer all of your questions

$>$ Don't ask personal questions

$>\quad$ Listen and write down the explanation from the informant who is being interviewed

$>$ Make a report based on the information you have obtained

Next, the interesting finding is in the exercise which is also completed with an interview format. The interview format is as follows. Notes on the Result of the Interview about Heat Energy Sources and Alternative Energy Sources are as follows:

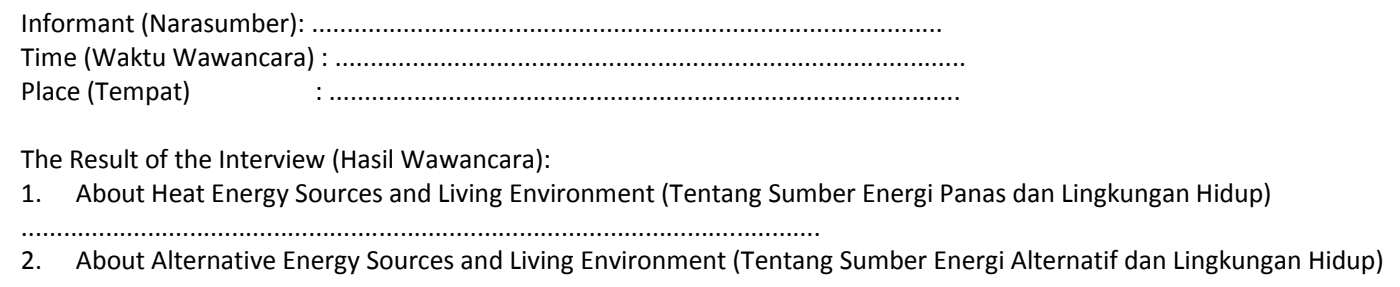

In the learning activity 6 , the activity is making a report of the result of the interview with a proper phase. 
Make a report of the result of the interview about alternative energy sources. If possible, type your report. If it is not possible, you can write your report in the following sheet.

Write the report neatly by using a good and correct Bahasa Indonesia.

A Report of the Result of the Interview

What follows is a text mentioned in the second sub-theme, "Conserving Energy at School".

\section{Bima's Activities at School (Kegiatan Bima di Sekolah)}

Today the fourth graders will make a vase out of clay. Every child shall make a vase according instance. They do make a practice of RUAG vase in the laboratory. Inside the room there are various props, measuring cups, materials and equipment to be used, tables, and chairs.

Before work, they listen to the explanation given by Mr. Guru. Finished listening to a briefing pack Master, Bhima and his friends eagerly make a vase which is exemplified by the teacher.

When the vase has been formed, they dry in a dry field. Any child who has completed, put the results of his work in front of the laboratory. After holding practices, Bhima and his friends hand washing. They use water to taste and turn off the water tap after use.

In the second sub-theme, language aspects are found in learning activity 1 to express gratitude by using a correct diction to socially interact with classmates in terms of the arrangement of words and sentences in living environment nuances. Write the expressions of gratitude in the form of actions based on the following situations! (p. 45)

No Situations (Keadaan)

1. At school, clean water is always sufficient for all students (Di sekolah tersedia air bersih yang selalu mencukupi untuk semua siswa)

2. At school, there is a beautiful garden created by all students (Di sekolah terdapat taman sekolah yang asri hasil usaha seluruh siswa)

3. Clean water flow through the school gutter (Selokan sekolah airnya mengalir jerrnih)

4. The pond at school is clean and there are some beautiful fish swimming (Kolam d sekolah bersih dan terdapat beberapa ekor ikan hias yang berenang)

5. The school yard is planted with shady trees and some of its leaves are falling (Halaman sekolah ditanami pohon yang rindang dan daunnya banyak yang berjatuhan)
My Actions (Tindakanku)

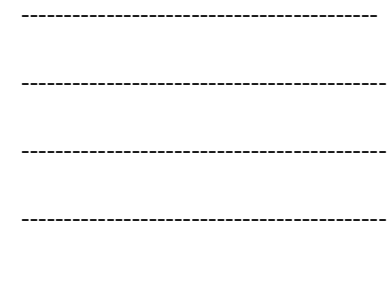

In learning activity 2, the exercise indicating the regular use of correct oral speech expression is found. Write a correct oral speech expression on the following cases and ask your parents about the appropriate response or action toward the following natural conditions (p. 45).

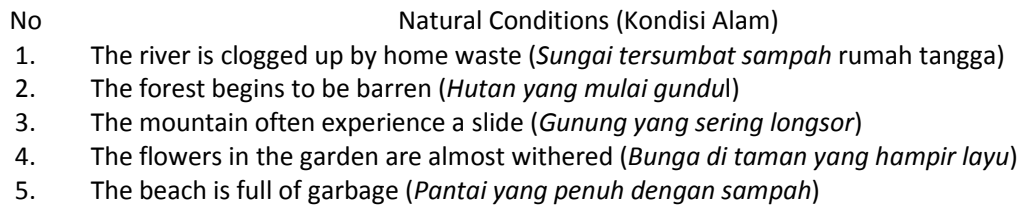

Actions (Tindakan)

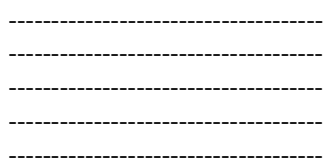

Next, the finding in learning activity 4 in the second sub-theme is a table to express how to take care of the environment through writing ability. Write down what you do to take care of the environment. Write your ways in the following table (p. 63).

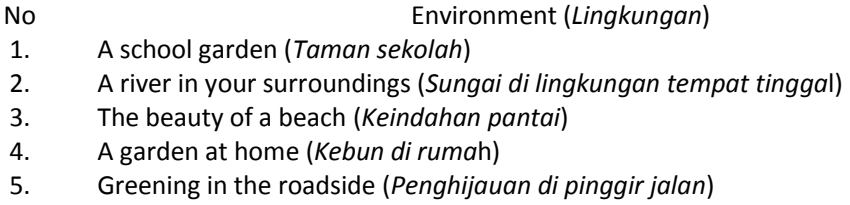

Ways to Take Care (Cara Merawat)

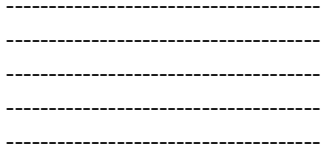


In the third sub-theme, Conserving Energy in the Society, learning activity 1 is found, that is formulating questions based on the text given.

\section{Holiday at Uncles Toni's House (Berlibur di Rumah Paman Toni)}

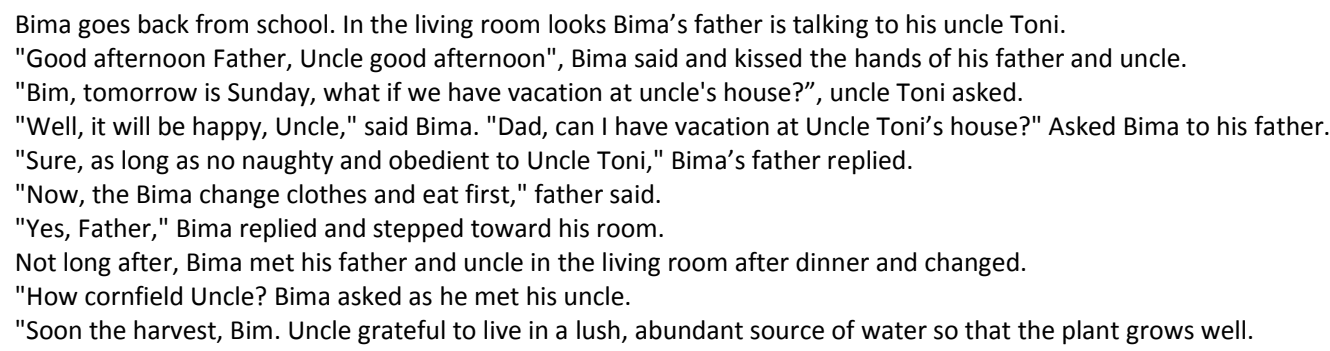

Let's write questions (p. 79). Bima wants to ask questions about the environment and natural resources that are found in the place where his uncle lives. Try to help Bima in writing the questions:

$>$ Write the questions to look for the information about environment!

$>$ Write the questions to look for the information about natural resources!

In learning activity 6 , in the third sub-theme, there is an exercise about making a report on utilizing energy sources (p. 108).

Arriving at Uncle Toni's house; Bima straight to his room and took his notebook. Bima wants to make a report during the holiday at uncle's house. (Sesampai di rumah Paman Toni. Bima langsung menuju kamarnya dan mengambil buku catatannya. Bima ingin membuat laporan selama liburan di rumah paman)

\section{Let's make a report}

Make a report based on the result of your observation about utilizing alternative energy sources in your area! Write it down in the following sheet!

A Report based on the Result of the Observation about Utilizing Alternative Energy Sources in the Environment

\section{Discussion and Recommendation}

One of the main goals of language teaching is to prepare students for meaningful interaction with natural language. To make the interaction meaningful to students, language learning program needs to be designed in depth. Language ability means students are skilled in using language as a communication tool. A skilled language user means having a good skill in listening, speaking, reading, and writing in the language learned. In elementary education level, the lesson material on living environmental problems as outlined in the system of the 2013 curriculum is delivered integratedly with other subjects. Through environmental education, it is expected that the students can start to be aware of environment since in elementary education; therefore, environmental destructions can be reduced. This environmental education can be done by utilizing a variety of learning environment) and a variety of approaches in learning about the environment through practical activities and direct experience (first-hand experience).

The findings indicate that teaching materials have been packed through the aspects of language that synergize with living environmental aspects. Learning a language is essentially learning how to communicate. Therefore, learning the language is directed to improve the learner's ability to communicate, in both oral and written modes with the theme "Always Conserving the Energy". Based on integrative thematic learning materials, the aspects of language in the nuances of environmental education are found in the form words arrangement, phrases arrangement, and sentences arrangement as seen in the learning activities 1 through 6; nevertheless, a literature aspect is not found at all. Hence, the findings of this study recommends that the learning 
process should be more interesting, and one of the ways to do it is through the poetry about the environment. What follows are two examples of poetry about the environment.

\section{Green World (Bumi Hijau)}

Green world a place I stay (Bumi hijau tempatku berdiri)

Here I grow up (Di sini aku tumbuh dan berkembang..)

Wind, water, land, trees are with me (Angin, air, tanah, pohon-pohon bersamaku)

Accompanying me while playing (Menemaniku bermain)

Accompanying me while joking (Menemaniku bercanda gurau)

Protecting me (Melindungiku ...)

How beautiful is my green world (Indah nian bumi hijauku)

Never do I want to destruct it (Tak ingin rasanya aku merusaknya)

I'll take care of the green world (Kan ku jaga bumi hijau)

Forever (Selamanya ...)

Not As Lovely As It Used To Be (Tak Seindah Dulu)

The sun shines, but it's not as lovely as it used to be (Mentari bersinar, tapi tak seindah dulu)

The forest's green, but it's not as green as it used to be (Hutan hijau, tak sehijau dulu)

The sky's clear, but it's not as clear as it used to be (Langit cerah, tak secerah dulu)

The sea's blue, but it's not as blue as it used to be (Laut biru, tak sebiru dulu)

The land's fertile, but it's not as fertile as it used to be (Tanah subur, tak sesubur dulu lagi)

The field, mount, it's not as lovely as it used to be (Sawah, gunung, kini tak seelok dulu lagi)

How beautiful is my environment... (Indahnya lingkunganku ...)

How beautiful is your environment... (Indahnya lingkunganmu ...)

But it'll never be as beautiful as it used to be (Tapi tak akan seindah dulu lagi ...)

Source: A collection of poetry about living environment written by ramadhana kurnia putra

Language learning which is not supported by learning material in the form of literary texts is a less perfect learning because language learning cannot be separated from learning the literature itself (Visuvalingam, 2000, p. 312). Thus, environmental poetry as a literary work of art can be studied from its various aspects both of its structure and its elements. The skills developed are the ability to catch the meaning, to play the role, to interpret, to assess, to express themselves by using language, and to understand the living environment through poetry. All of them are grouped into language, understanding, and poetry usage. Environmental education is an attempt to change the students' behavior and attitudes implemented to improve their knowledge, skills, and awareness of environmental values since elementary education so that they can play an active role in the effort of preserving and saving the environment.

\section{References}

Atherton, J. S. (2005). Learning and teaching: Humanistic approaches to learning Pedagogy (2th ed.). New York.

Black, J. B., \& R. O. McClintock. (1995). Constructivist learning environment. New Jersey: Englewood Cliff, Educational Technology Publications.

Brown. H. D. (2000). Principles of language learning and teaching (4th ed.). New York.

Creswel, J. W. (2010). Research design: Pendekatan kualitatif, kuantitatif, dan mixed (Translated by Achmad Fawaid). Yogyakarta: Pustaka Pelajar.

Danusaputro, S. M. (1981). Environmental education and training. Bandung: Binacipta Publishing Company. Hadley, A. O. (1993). Teaching language (2th ed.). USA: Heinle and Heinle Publishers.

James, S. A., \& Stapp, W. B. (1974). Environmental education. New York: John Willey \& Sons.

Miles, M., \& Huberman, M. (1994). Qualitative data analysis (2nd ed.). Beverly Hills, CA: Sage.

Suryabrata, S. (1998). Psikologi Pendidikan. Jakarta: PT Raja Grafindo Persada.

Teew, A. (1983). Membaca dan menilai sastra. Jakarta: Gramedia

Visuvalingam, E. (2000, 17- 21 July). Apprendre par la littérature: pour une didactique du texte littéraire en FLE. Paper presented at Actes du Xe Congrès mondial des professeurs de français, Paris.

Wellek, R., \& Warren, A. (1990). Teori kesusasteraan. Terjemahan. Jakarta: Gramedia. 